
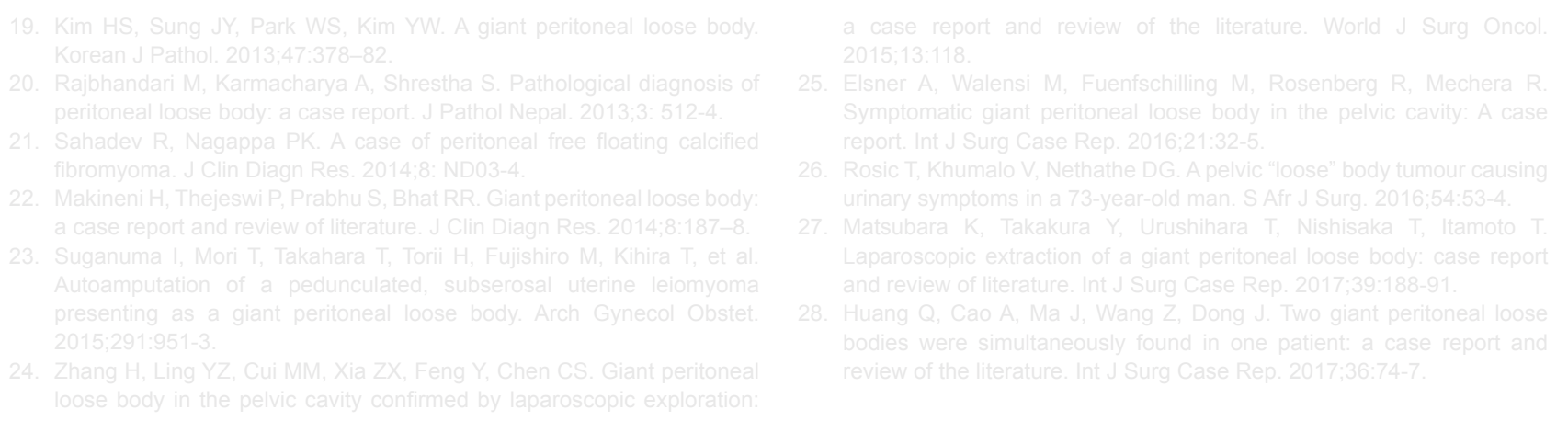

\title{
Hepatic Abscess Induced by Fish Bone Migration: Two Case Reports
}

\section{Abcesso Hepático Induzido por Migração de Espinha de Peixe: Dois Casos Clínicos}

\author{
José Eduardo MATEUS ${ }^{1}$, Carlos SILVA¹, Sofia BEIRÃO², Jorge PIMENTEL ${ }^{2}$ \\ Acta Med Port 2018 May;31(5):276-279 - https://doi.org/10.20344/amp.9662
}

\section{ABSTRACT}

Although foreign body ingestion is a common occurrence, perforation and penetration of the gastrointestinal tract is unusual and the development of a hepatic abscess is even more rare. The authors describe two cases of fish bone perforation of the gastrointestinal tract with hepatic perforation and abscess formation, from distinctive age groups and varying presentation, although both developed septic shock. The lack of history of ingestion of foreign bodies, non-specificity of both clinical presentation and complementary examinations all play a role in delaying the diagnosis and therefore in the prognosis itself.

Keywords: Fishes; Foreign Bodies; Intestinal Perforation; Liver Abscess

\section{RESUMO}

Embora a ingestão de corpo estranho seja uma situação relativamente comum, a perfuração e penetração do trato gastrointestinal é pouco frequente e a formação de um abcesso hepático é ainda mais rara. Os autores descrevem dois casos de perfuração do trato gastrointestinal por espinha de peixe com formação de abcesso hepático, pertencentes a grupos etários distintos e com diferente apresentação clínica, embora ambos tenham desenvolvido choque séptico. A ausência de história de ingestão de corpo estranho, a inespecificidade dos resultados dos exames complementares e das manifestações clínicas contribuem para um atraso no diagnóstico e, também por isso, influenciam o próprio prognóstico.

Palavras-chave: Abcesso Hepático; Corpo Estranho; Peixes; Perfuração Intestinal

\section{INTRODUCTION}

Although foreign body ingestion is a common occurrence, in most cases the ingested object will pass through the gastrointestinal $(\mathrm{Gl})$ tract without causing any damage..$^{1,2}$ Perforation and penetration of the GI tract is unusual and the development of an hepatic abscess is even more rare. ${ }^{3-6}$ As patients hardly ever recall the ingestion event and clinical presentation can be so diverse and nonspecific, diagnosis can be challenging. ${ }^{13,4,7}$

In this report we describe two cases of fish bone perforation of the $\mathrm{Gl}$ tract with hepatic perforation and abscess formation that illustrate the difficulty of diagnosis and emphasize the need for attention towards this rare but serious condition.

\section{CASE REPORTS}

Case 1

A 76-year-old man presented with a three-day history of abdominal pain and constipation. He had no significant medical history. Physical examination revealed distended abdomen, without any sign of acute abdomen. Laboratory investigations showed leukocytosis $(21300 / \mu \mathrm{L})$, elevated C-reactive protein $(34.9 \mathrm{mg} / \mathrm{dL})$, elevated liver enzymes (alanine transaminase $251 \mathrm{U} / \mathrm{L}$; aspartate transaminase $415 \mathrm{U} / \mathrm{L}$; alkaline phosphatase $204 \mathrm{U} / \mathrm{L}$ ) and elevated bilirubin level (33 $\mu \mathrm{mol} / \mathrm{L})$.

Abdominal ultrasound found a $9 \mathrm{~cm}$ heterogeneous lesion in the liver. Abdominal computed tomography (CT) scan (Fig. 1) showed a peripherally enhancing multiloculated lesion measuring $8.7 \times 8.2 \mathrm{~cm}$ in the left lobe and a hyperdense linear foreign body in its posterior wall.

\footnotetext{
1. Serviço de Medicina Interna A. Centro Hospitalar e Universitário de Coimbra. Coimbra. Portugal.

2. Serviço de Medicina Intensiva. Centro Hospitalar e Universitário de Coimbra. Coimbra. Portugal.

$\triangle$ Autor correspondente: José Eduardo Mateus. zeduardomateus@gmail.com

Recebido: 10 de setembro de 2017 - Aceite: 06 de fevereiro de 2018 | Copyright @ Ordem dos Médicos 2018
} 


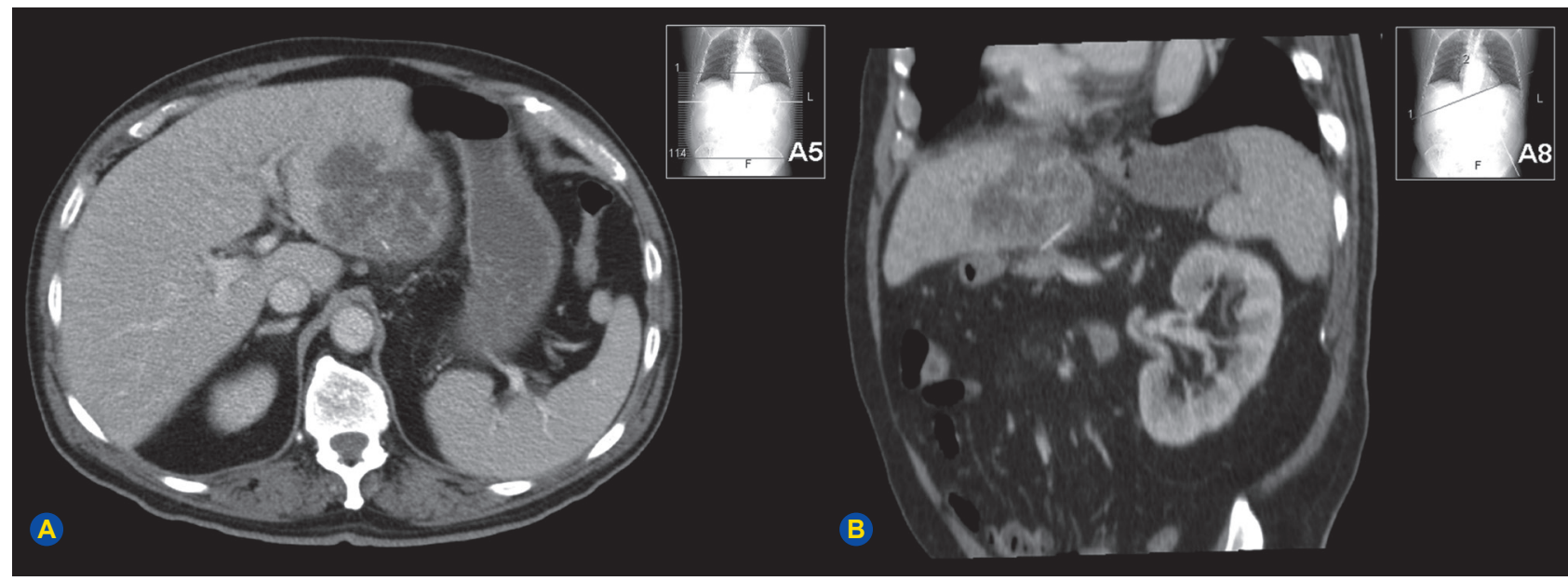

Figure 1 - Multiloculated lesion in the left lobe of the liver $(A)$ and a hyperdense linear foreign body in its posterior wall $(B)$

In spite of antibiotic therapy and percutaneous abscess drainage under ultrasonographic guidance, the patient's condition deteriorated (dyspnea, prostration and elevated lactate level). Laparotomy was then performed, the abscess was drained and a $5 \mathrm{~cm}$ long fish bone was removed from the hepatic left lobe. The patient was admitted to the intensive care unit. One week later he was still hemodynamically unstable and feverish, so segmentectomy II and III was carried out with clinical improvement. The patient was given piperacillin/tazobactam and levofloxacin. Streptococcus constellatus was isolated from both blood and pus culture. The patient was discharged two weeks later stable and well. Subsequent abdominal ultrasounds performed months later showed complete resolution of the hepatic abscess.

\section{Case 2}

A 45-year-old man presented with a two-day history of weakness, chills, myalgias and productive cough. He had a history of schizophrenia and was treated with lorazepam, olanzapine and pantoprazole. On examination he was tachycardic (heart rate: 145 beats per minute) and hypotensive (blood pressure: $86 / 47 \mathrm{mmHg}$ ). Laboratory data revealed normal hemoglobin, leukocytes and platelet counts with altered renal function (blood urea nitrogen $57.4 \mathrm{mg} / \mathrm{dL}$ and serum creatinine $1.6 \mathrm{mg} / \mathrm{dL}$ ), elevated liver enzymes (alanine transaminase $72 \mathrm{U} / \mathrm{L}$; aspartate transaminase $87 \mathrm{U} / \mathrm{L}$; alkaline phosphatase $185 \mathrm{U} / \mathrm{L}$ ) and elevated C-reactive protein $(23 \mathrm{mg} / \mathrm{dL})$. Plain radiograph of the chest was normal.

Clinical diagnosis of septic shock was carried out, unresponsive to ceftriaxone, fluid challenge, dopamine and noradrenaline. Twenty-four hours after hospital admission the patient complained of severe epigastric pain. Abdominal ultrasound revealed a hypoechoic lesion in the liver. Abdominal CT scan (Fig. 2) showed a peripherally enhancing multi-loculated lesion in segment IVb measuring $5.7 \times 5.3 \times 4.5 \mathrm{~cm}$ consistent with hepatic abscess, surrounding a hyperdense linear foreign body - a fish bone.

Using CT guidance, the hepatic abscess was drained percutaneously. The patient was admitted to the intensive care unit and was started on piperacillin/tazobactam and metronidazole with clinical improvement. Two blood cultures isolated Streptococcus anginosus and microbiological examination of the drained fluid was positive for Streptococcus viridans, Prevotella bivia and Bacteroides fragilis. Three weeks later the patient was discharged and maintained antibiotic therapy. Follow-up CT imaging performed four months later showed resolution of the hepatic abscess and the fish bone remained unchanged.

\section{DISCUSSION}

GI perforation has been reported in less than $1 \%$ of patients with ingested foreign bodies..$^{4-6}$ It happens mostly when sharp objects are involved, like fish bones, chicken bones or toothpicks. ${ }^{1,5,6}$ Stomach and duodenum are the most common sites of gut perforation. ${ }^{4,5}$ In a review by Sofia et al, fish bone migration was the commonest type of foreign body to give rise to the development of liver abscesses. ${ }^{4}$

Since the migrating foreign body may remain silent until an abscess forms, most patients have non-specific symptoms (anorexia, fever, vomiting) secondary to inflammatory systemic response. ${ }^{3,4}$ The classic triad of hepatic abscess (fever, abdominal pain and jaundice) is uncommon. ${ }^{3,4}$ Furthermore, the onset of symptoms can vary from one week to three months after ingestion. ${ }^{3} \mathrm{We}$ report two very different cases, from distinctive age groups and varying presentation, although both developed septic shock. None of the patients had memory of mis-swallowing any foreign body, which is in agreement with previously reported cases. ${ }^{1,3,4}$

Routine laboratory studies are also non-specific. Plain radiography is not useful in detecting foreign bodies unless they are radiopaque. Abdominal ultrasound is helpful for the diagnosis but CT scan is the preferred technique as it offers both high resolution and accuracy. ${ }^{3,4,6,8}$ Endoscopy may be helpful when performed early and before migration of the foreign body has taken place. ${ }^{8}$

Streptococcus constellatus and Streptococcus anginosus are members of the Streptococcus milleri group. They are found among normal oropharyngeal and 


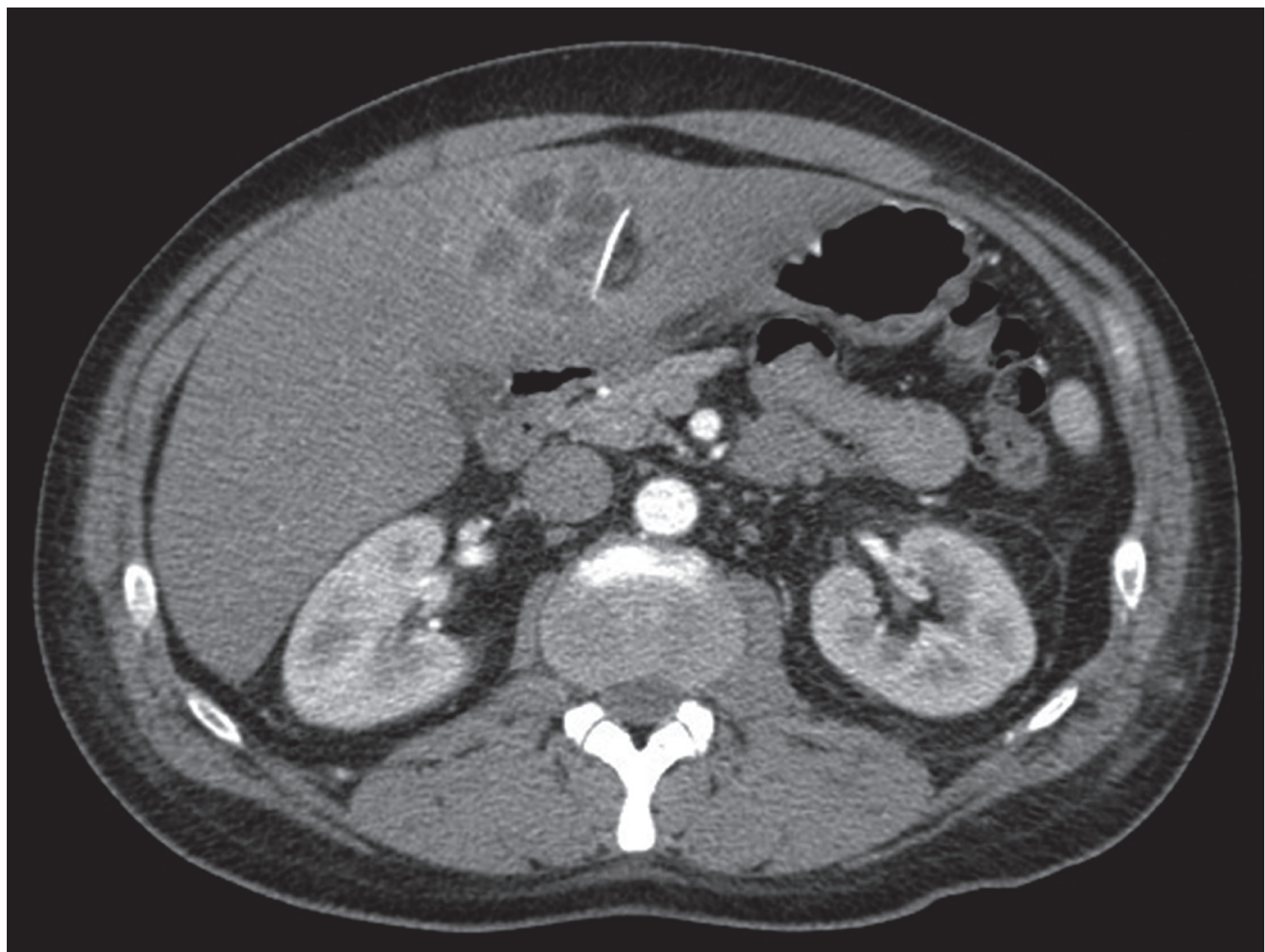

Figure 2 - Multiloculated lesion in hepatic segment IVb surrounding a hyperdense linear foreign body

GI flora. ${ }^{6,9,10}$ Their unique characteristic that sets these streptococci apart from other pathogenic streptococci is their ability to cause abscesses. ${ }^{9,10}$ Bacteremia from the Streptococcus milleri group is infrequent but must trigger the search for an underlying abscess. ${ }^{10}$ In the second case report, the patient complained of abdominal pain only after going into septic shock. In both cases this group of streptococci was isolated from blood cultures and/or pus culture. Knowledge of each bacteria's predilection for different clinical presentations can aid in determining the location of the underlying source of infection. ${ }^{10}$

The treatment of hepatic abscess remains controversial, ranging from antibiotic therapy to percutaneous drainage and open surgery. ${ }^{3}$ In most reported cases, fish bone induced liver abscesses were treated by drainage of the abscess and removal of the foreign body either by surgical or percutaneous approaches as well as using antimicrobial therapy. Surgical treatment is as effective as the percutaneous route. Although more invasive, surgery is the corner stone management if perforation of the gut is suspected. . $^{3,4,8}$

The prognosis depends on quick diagnosis. Two fatal liver abscesses due to fish bone migration have been reported so far. ${ }^{11,12}$

\section{PROTECTION OF HUMANS AND ANIMALS}

The authors declare that the procedures were followed according to the regulations established by the Clinical Research and Ethics Committee and to the Helsinki Declaration of the World Medical Association.

\section{DATA CONFIDENTIALITY}

The authors declare having followed the protocols in use at their working center regarding patients' data publication.

\section{PATIENT CONSENT}

Obtained.

\section{CONFLICTS OF INTEREST}

All authors report no conflict of interest.

\section{FUNDING SOURCES}

This research received no specific grant from any funding agency in the public, commercial, or not-for-profit sectors. 


\section{REFERENCES}

1. Cheung YC, Ng SH, Tan CF, Ng KK, Wan YL. Hepatic inflammatory mass secondary to toothpick perforation of the stomach: triphasic CT appearances. Clin Imaging. 2000;24:93-5.

2. Tsui BC, Mossey J. Occult liver abscess following clinically unsuspected ingestion of foreign bodies. Can J Gastroenterol. 1997;11:445-8.

3. $\mathrm{Ng} \mathrm{CT}$, Htoo A, Tan SY. Fish bone-induced hepatic abscess: medical treatment. Singapore Med J. 2011;52:e56-8.

4. Santos SA, Alberto SC, Cruz E, Pires E, Figueira T, Coimbra E, et al. Hepatic abscess induced by foreign body: case report and literature review. World J Gastroenterol. 2007;13:1466-70.

5. Chintamani, Singhal V, Lubhana P, Durkhere R, Bhandari S. Liver abscess secondary to a broken needle migration - a case report. BMC Surg. 2003;3:8.

6. Horii K, Yamazaki O, Matsuyama M, Higaki I, Kawai S, Sakaue Y. Successful treatment of a hepatic abscess that formed secondary to fish bone penetration by percutaneous transhepatic removal of the foreign body: report of a case. Surg Today. 1999;29:922-6.

7. Venkatesh SH, Sanamandra SK. Large hepatic abscess caused by fish bone. Saudi Med J. 2015;36:878-9.

8. Masoodi I, Alsayari K, Al Mohaimeed K, Ahmad S, Almtawa A, Alomair A, et al. Fish bone migration: an unusual cause of liver abscess. BMJ Case Rep. 2012;2012.pii:bcr0920114838.

9. Bateman NT, Eykyn SJ, Phillips I. Pyogenic liver abscess caused by Streptococcus milleri. Lancet. 1975;1:657-9.

10. Ng KW, Mukhopadhyay A. Streptococcus constellatus bacteremia causing septic shock following tooth extraction: a case report. Cases J. 2009;2:6493.

11. Theodoropoulou A, Roussomoustakaki M, Michalodimitrakis MN, Kanaki C, Kouroumalis EA. Fatal hepatic abscess caused by a fish bone. Lancet. 2002;359:977.

12. de la Vega M, Rivero JC, Ruíz L, Suárez $\mathrm{S}$. A fish bone in the liver. Lancet. 2001;358:982. 